The Israeli Journal of Aquaculture IJA.73.2021.1531522, 24 pages

CCBY-NC-ND-4.0 • https://doi.org/10.46989/001c.29633

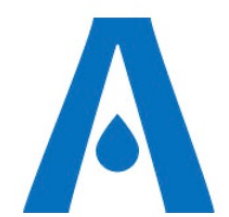

The $I J A$ is a peer-reviewed open-access, electronic journal, freely available without charge to users

Produced by the AquacultureHub non-profit Foundation Sale of $I J A$ papers is strictly forbidden

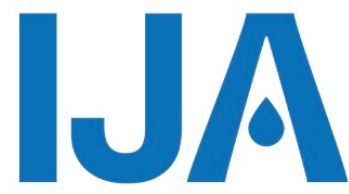

\title{
High prevalence of Aeromonas and Pseudomonas infections among cage cultured Pangas catfish from the reservoirs of Maharashtra, India
}

\author{
R. Bharathi Rathinam ${ }^{1}$, Husne Banu ${ }^{1}$, Gajanan S. Ghode ${ }^{3}$, Shashi \\ Bhushan $^{2}$, Rathi Bhuvaneswari ${ }^{1}$, Gayatri Tripathi ${ }^{1 *}$
${ }^{1}$ Aquatic Environment and Health Management Division, ICAR-Central Institute of Fisheries Education, Mumbai, India - 400061
Education, Mumbai, India - 400061
${ }^{3}$ Department of Aquaculture, College of Fisheries, Ratnagiri, India - 415629 \\ ${ }^{2}$ Department of Fisheries Resource Management, ICAR-Central Institute of Fisheries
}

Key words: Cage culture; Pangasius catfish; Bacterial infection; Histopathology; Principal Component Analysis

\begin{abstract}
Cage farming of Pangas catfish (Pangasionodon hypophthalmus) in small reservoirs is primarily profitable. Still, sustainability in terms of disease and environmental impact issues remains unsolved. In the present study, Pangas catfish from selected farms were screened for bacteria and parasites from 2017-18. In the present study, several Gram-negative bacterial species, including Edwardsiella tarda, Aeromonas hydrophila, A. veronii, Pseudomonas putida, Enterobacter cloacae, and Plesiomonas shigelloides, were isolated. A high prevalence of Aeromonas and Pseudomonas infections was noticed in cage farms. The most prevalent isolate was $A$. veronii ( 9 isolates), followed by $P$. aeruginosa and $P$. putida, revealing the presence of biotic stress.

Furthermore, potential human pathogenic bacteria, particularly Klebsiella pneumoniae, P. aeruginosa, Acinetobacter baumannii, Citrobacter freundii, and Morganella morganii, were isolated. Histopathological analysis of the vital organs concluded the extent of damage caused due to the biotic stress in the cage culture system. The antibiotic sensitivity test implied resistance of bacteria for Sulphamethoxazole and Tetracycline. Some of them were resistant to multiple drugs, the risk for public health. Water temperature, dissolved oxygen, $\mathrm{pH}$, Aeromonas, Pseudomonas, and Plesiomonas were identified by principal component analysis as significant abiotic and biotic stress factors. This information helps design predictive disease models.
\end{abstract}

* Corresponding author. E-mail: gayatrit@cife.edu.in, Tel No: +91 9757442680 


\section{Introduction}

Cage culture of Pangas catfish (Pangasianodon hypophthalmus) in India was started in 2012. The high stocking density and better growth rate make it suitable for cage farming in small and large reservoirs. However, the frequency of disease outbreaks is more in cage cultured fish than in ponds (Collins, 1988; Masser, 1991). Poor water quality parameters and improper management practices such as high stocking, overfeeding, inadequate nutrition, etc. also increase stress to the fish and thus make them more susceptible to disease outbreaks (Boyd \& Tucker, 1998; Zamri-Saad et al. 2014). Reports on cage cultured Pangas catfish diseases from Indian water bodies are infrequent (Kumar et al. 2013 ; 2015), whereas many of cases have been reported from Vietnam. Most of the diseases are due to bacteria namely, $A$. hydrophila $A$. sobria, and $A$. caviae, $A$. jandaei (Ferguson et al. 2001; Crumlish et al. 2001; Kumar et al. 2015) causing Motile Aeromonad Septicemia (MAS) and Edwardsiella ictaluri causing Bacillary Necrosis of Pangasius (BNP). However, many prevalent bacteria and parasites, i.e., Aeromonas, Pseudomonas, Streptococcus (Austin \& Austin, 2012; Amal et al. 2013; Chitmanat et al. 2016), Edwardsiella (Phan et al. 2009; Shetty et al. 2014), Trichodina (Chitmanat et al. 2016) and Myxosoma are reported to cause diseases in different cage cultured fishes.

Abiotic factors associated with the aquaculture system can significantly affect the health of the cultured animal. In an open water culture system, water quality fluctuation is higher influencing the bacterial diversity (Vezzulli et al. 2002). The optimal range of water quality parameters varies from species to species and should be monitored to achieve better growth and survival. Therefore, it is considered as a critical factor in the aquafarming industry. Despite massive Pangasius farming, some reports deal with their disease predictive model and management strategies (NFDB, 2016). In this context, the present research was carried out to understand the prevalence of the bacterial pathogens in the cage cultured $P$. hypophthalmus in selected reservoirs of Maharashtra (Panshet, Varasgaon, Kanher, and Manoli).

Furthermore, to find significant biotic and abiotic factors associated with the cage culture of pangasius catfish, Principal Component Analysis (PCA) was also carried out. The periodic data of prevalent pathogens would be helpful for disease prediction and control. Antimicrobial resistance is a burning topic for humans, and thus have also carried out antibiotic sensitivity tests to assist with cage culture bacterial pathogens.

Details of sampling

\section{Materials and Methods}

The sampling was conducted periodically from September 2017 to May 2018 in cage farms situated in various reservoirs of Maharashtra (Figure 1), i.e., Farm I (Panshet), Farm II (Varasgaon), Farm III (Kanher), and Farm IV (Manoli). The details of reservoirs and cages are mentioned in Table 1. Two stations were fixed in each cage for the collection of water and soil samples. The water samples were taken from various points at each cage and mixed to get a representative sample. Water quality parameters namely water temperature, $\mathrm{pH}$, dissolved oxygen, ammonia- $\mathrm{N}$, and nitrite- $\mathrm{N}$ were analyzed using APHA (2005). A total of 20 fishes, both healthy and diseased, were randomly collected from each reservoir in every sampling with an average size of $215 \mathrm{~g}-450 \mathrm{~g}$. Some of them exhibited petechial hemorrhagic lesions on the body surface and pectoral-fin base, reddening of mouth, abnormal swimming pattern, lethargic movement, and tail rot (Figure 2). The fishes were brought to the laboratory in live condition for further analysis.

Bacterial and parasitic examination

External and internal organs, i.e., skin mucus, gill, fin, kidney, liver, and gall bladder were observed under the microscope for external and internal parasitic examination. Fishes were surface sterilized with $70 \%$ alcohol to avoid any unwanted bacterial contamination. A sterilized loop was inserted into the external lesions, kidney, liver, and gill and aseptically streaked on Brain heart infusion agar and incubated for $18-24 \mathrm{hr}$ at $25-28^{\circ} \mathrm{C}$. Isolated colonies were further streaked on selective agar, i.e., Aeromonas isolation agar, SS agar, and GSP agar. The pure culture was used for biochemical and molecular characterization. Presumptive biochemical tests such as gram staining, oxidase, and catalase were done 
using standard procedures, and further characterization was done using the biochemical identification kit (HiMedia Ltd, Mumbai).

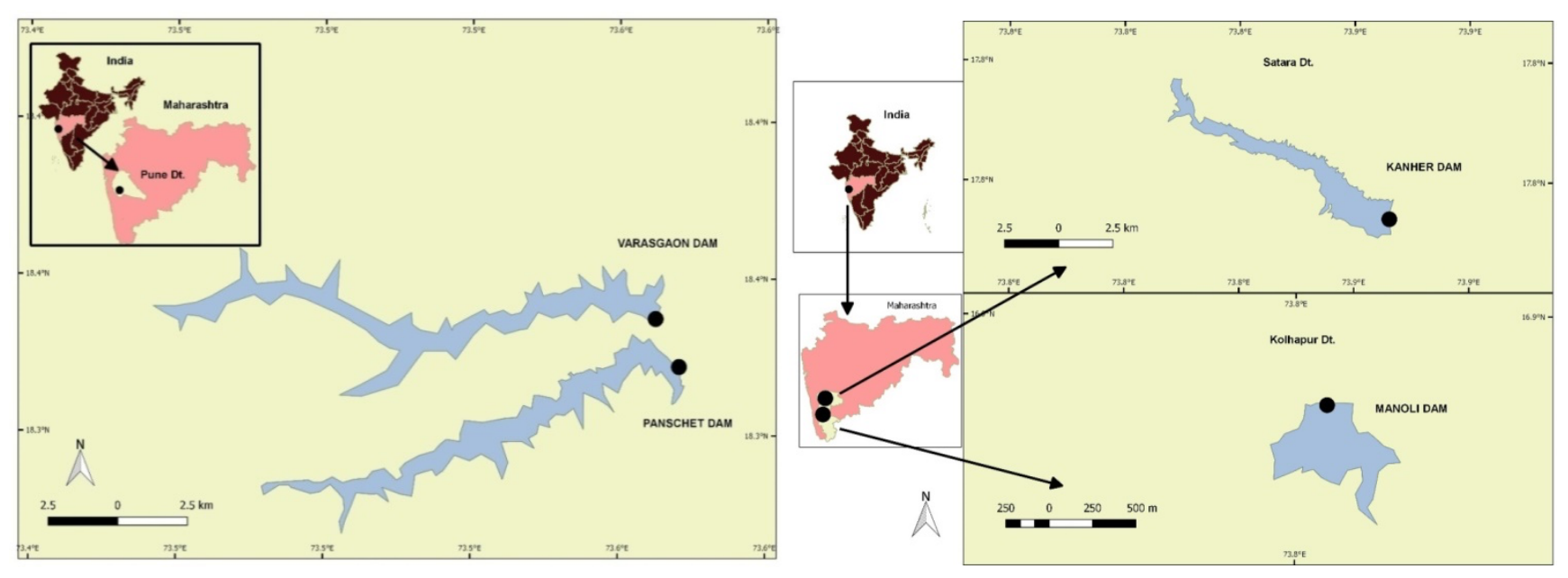

Figure 1 Sampling Location of the present study in Maharashtra.

Table 1 Characteristics of selected reservoirs and cage farms

\begin{tabular}{|c|c|c|c|c|}
\hline Cage farms & Farm I & Farm II & Farm III & Farm IV \\
\hline $\begin{array}{l}\text { Location of } \\
\text { cages }\end{array}$ & $\begin{array}{c}18^{\circ} 22^{\prime} 24.7296^{\prime \prime} \mathrm{N} \\
73^{\circ} 36^{\prime} 4.2408^{\prime \prime} \mathrm{E}\end{array}$ & $\begin{array}{l}18^{\circ} 23^{\prime} 23.0784^{\prime \prime} \mathrm{N} \\
73^{\circ} 35^{\prime} 54.9312^{\prime \prime} \mathrm{E}\end{array}$ & $\begin{array}{l}16^{\circ} 37^{\prime} 41.3508^{\prime \prime} \mathrm{N} \\
74^{\circ} 16^{\prime} 48.4896^{\prime \prime} \mathrm{E}\end{array}$ & $\begin{array}{c}16^{\circ} 56^{\prime} 52.7604^{\prime \prime} \mathrm{N} \\
73^{\circ} 48^{\prime} 28.6776^{\prime \prime} \mathrm{E}\end{array}$ \\
\hline $\begin{array}{l}\text { Name of the } \\
\text { reservoir }\end{array}$ & Panshet & Varasgaon & Kanher & Manoli \\
\hline $\begin{array}{l}\text { Area of the } \\
\text { reservoirs }\end{array}$ & 870ha & 1180ha & 350ha & 300 ha \\
\hline $\begin{array}{l}\text { Depth of the } \\
\text { reservoirs }\end{array}$ & $48 m$ & $50 \mathrm{~m}$ & $16 \mathrm{~m}$ & $18 \mathrm{~m}$ \\
\hline $\begin{array}{l}\text { Number of } \\
\text { cages }\end{array}$ & $\begin{array}{c}50 \\
(5 \times 5 \times 3.5 \mathrm{~m})\end{array}$ & $\begin{array}{c}150 \\
(5 \times 5 \times 3.5 \mathrm{~m})\end{array}$ & $\begin{array}{c}8 \\
(6 \times 7 \times 4 m)\end{array}$ & $\begin{array}{c}48 \\
(4 \times 6 \times 5 m)\end{array}$ \\
\hline Stocking density & $\begin{array}{l}6500 / \text { cage } \\
\text { wt. } 25-30 \mathrm{~g}\end{array}$ & $\begin{array}{l}6500 / \text { cage } \\
\text { wt. } 25-30 \mathrm{~g}\end{array}$ & $\begin{array}{l}6000 / \text { cage } \\
\text { wt. } 20-25 \mathrm{~g}\end{array}$ & $\begin{array}{l}4000 / \text { cage } \\
\text { wt. } 20-25 \mathrm{~g}\end{array}$ \\
\hline
\end{tabular}



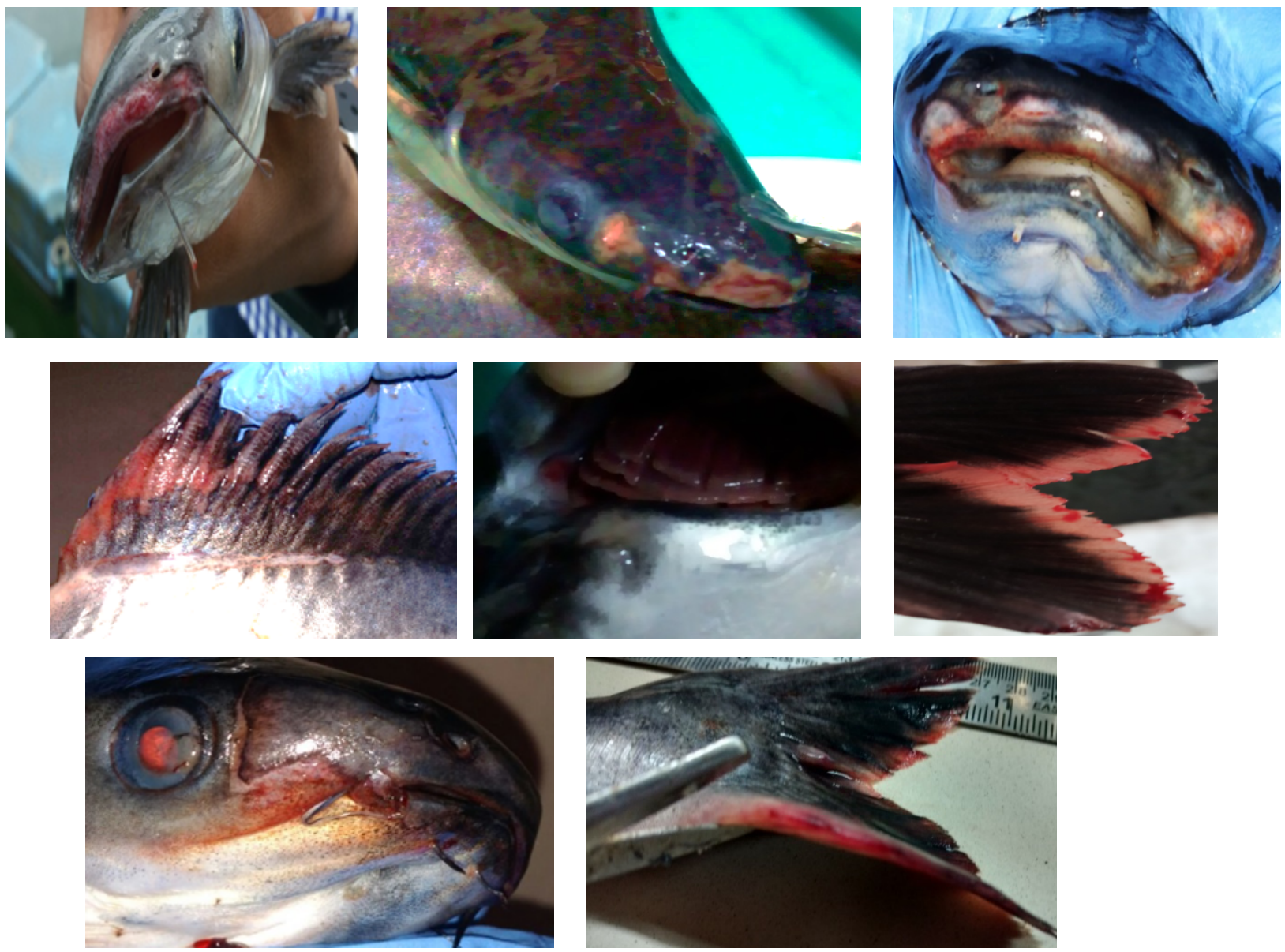

Figure 2 The fish samples collected for bacteriological analysis displaying clinical symptoms

Molecular characterization of the isolates

Bacterial DNA isolation was done using the CTAB method and quantified using Nanodrop2000 (Thermo-scientific, USA). Molecular identification of the bacterial isolates was carried out by $16 \mathrm{~s}$ rRNA gene sequencing, using universal $16 \mathrm{~s}$ rRNA primers. The forward and reverse primer sequences were 5'-AGAGTTTGATCCTGGCTCAG-3' and 5'GGTTACCTTGTTACGACTT-3' respectively (Sarkar et al. 2012). PCR protocol was performed by using $25 \mu \mathrm{l}$ of a PCR mixture containing $2 \mu \mathrm{l}$ of $50 \mathrm{ng}$ DNA template, $1 \mu \mathrm{l}$ of $10 \mathrm{pmol}$ of each specific primer, $1 \mu \mathrm{l}$ of $200 \mu \mathrm{M}$ dNTPs, $0.5 \mu \mathrm{l}$ of Taq DNA polymerase, and $2.5 \mu \mathrm{l}$ of $1 \mathrm{x}$ Taq polymerase buffer containing $1.5 \mathrm{mM} \mathrm{MgCl}_{2}$. PCR amplification was carried out with the following temperature program: 1 cycle of denaturation for $5 \mathrm{~min}$ at $95^{\circ} \mathrm{C} ; 35 \mathrm{cycles}$ of melting at $95^{\circ} \mathrm{C}$ for $30 \mathrm{~s}$, annealing at $55^{\circ} \mathrm{C}$ for $30 \mathrm{~s}$, and elongation at $72^{\circ} \mathrm{C}$ for $1 \mathrm{~min}$; and a final extension at $72^{\circ} \mathrm{C}$ for $10 \mathrm{~min}$ and then held at $4^{\circ} \mathrm{C}$. PCR amplicons were separated electrophoretically by loading PCR product in $1.5 \%$ agarose gel. The target amplicon bands were purified using the StrataPrep DNA Gel Extraction Kit (Agilent Technologies, USA), following the manufacturer's protocol. The purified 16s rRNA gene amplicons of the bacterial isolates were sequenced using commercial services of Xcelris Labs Ltd. (Bangalore). The single nucleotide-nucleotide alignment was performed to find the homologous sequence using the Basic Local Alignment Search Tool (BLAST) of the National Centre for Biotechnology Information (NCBI) (Figure 3). 


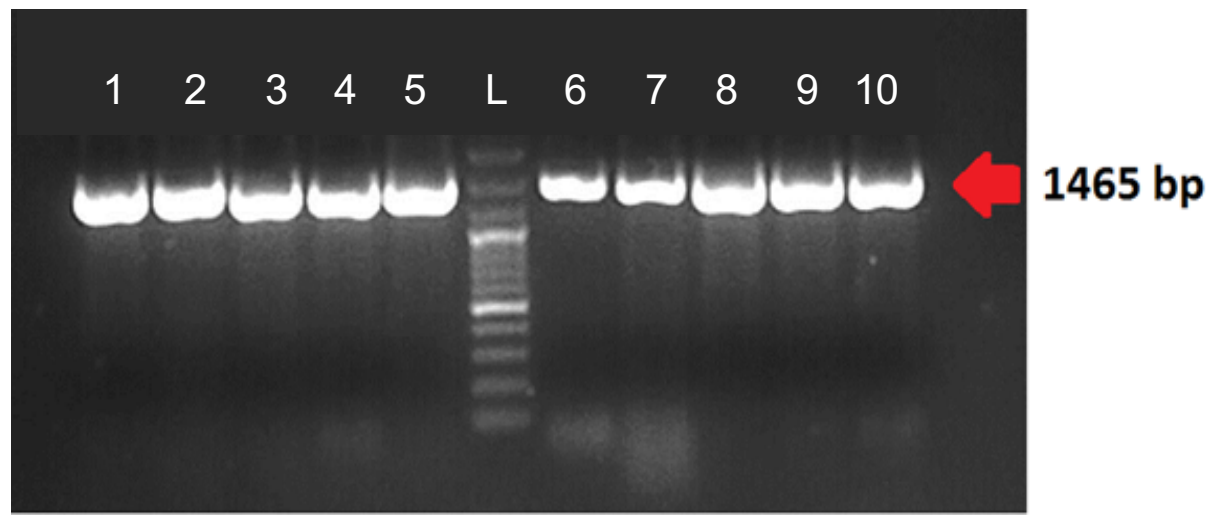

Figure 3 16s rRNA gene PCR amplification of the isolated bacterial pathogens using universal 16s rRNA primers (Sarkar et al., 2012) displaying distinct bands at 1465 bp. Lane L: 100bp plus ladder (Image analyzed by Gel Doc System, 2000, Biorad).

\section{Histopathological analysis}

Histopathological analysis for the vital tissues of fishes isolated with Aeromonas, Pseudomonas $s p$ as well as healthy fishes was carried out to compare tissue level alterations. The vital tissues (liver, kidney, gill, and intestine) were collected and preserved in $10 \%$ neutral buffered formalin for histopathological analysis. Tissues were dehydrated with a series of alcohol gradients and cleared by using xylene. The dehydrated tissues were embedded in paraffin wax following the impregnation technique (Leica, EG $1140 \mathrm{H}$, Germany). The embedded wax blocks were sectioned at 3-5 $\mu \mathrm{m}$ thickness using a microtome (Leica RM 2125RT, Germany) and stained with hematoxylin and eosin (Luna, 1968).

\section{Antibiotic susceptibility}

Disc diffusion method, also called as Kirby-Bauer test was carried out for screening sensitive and resistant bacteria against 10 different antibiotics namely, Ampicillin $(25 \mathrm{mcg})$, Tetracycline $(10 \mathrm{mcg})$, Ciprofloxacin $(30 \mathrm{mcg})$, Gentamicin $(50 \mathrm{mcg})$, Sulphamethoxazole (25 mcg), Kanamycin (5 mcg), Streptomycin (25 mcg), Chloramphenicol (30 mcg), Penicillin - G (2 units) and Neomycin $(30 \mathrm{mcg})$. The $24 \mathrm{~h}$ fresh bacterial culture was spread over Mueller Hinton agar plates. The antibiotic discs were placed aseptically on agar and incubated for $24 \mathrm{~h}$ at $25^{\circ} \mathrm{C}$. The presence or absence of an inhibitory area around the disc was measured in $\mathrm{mm}$ and the results were recorded. The zone sizes were compared and isolates were classified as sensitive, resistant, or intermediate according to the guidelines of the Clinical and Laboratory Standards Institute (CLSI, 2009).

\section{Water quality parameter analysis}

Two stations were fixed in each cage for the collection of water samples. Water samples were taken from various points in each cage and mixed to get a representative sample. Water quality parameters such as water temperature, $\mathrm{pH}$, dissolved oxygen, ammonia- $\mathrm{N}$, and nitrite-N were analyzed by using APHA (2005).

\section{Statistical analysis}

Statistical analysis of mean \pm SD of water quality data was measured and compared between each farm and samplings using one-way ANOVA with Duncan's multiple range test (Duncan, 1955) through SPSS 16.0. The number of bacteria isolated from each farm and their percentage during the study period was calculated. P-value at $<0.05$ was used to specify statistical significance. A dataset was prepared with the percentage of all isolated bacteria and all water quality data in each sampling and analyzed separately for each cage farm. Parameters that exhibited significant variation in their values were computed in MS Excel for further analysis using PAleontological STatistics (PAST) software package. The association between various water quality parameters in the relevance of bacterial load was studied using Principal Component Analysis (PCA). The PCA was examined using PAST The Israeli Journal of Aquaculture - Bamidgeh • IJA.73.2021.1531522 
Software (Version 3.1.0). The summary statistics explained with minimum-maximum range, standard deviation, and variance for various water quality parameters and bacterial prevalence were calculated separately for each farm and used for further analysis.

\section{Results}

Isolation and identification of bacteria

A total of 21 bacterial species were identified and characterized by using 16s rRNA gene sequencing (Fig. 3). The identified bacteria were Pseudomonas $s p$ (6 nos), Aeromonas $s p$ (3 nos), Acinetobacter $s p$ (3 nos), Citrobacter $s p$ (2 nos), Enterobacter $s p$ (2 nos), $P$. shigelloides, Klebsiella pneumonia, Morganella morganii, Lactococcus lactis, and E. tarda. The 16s rRNA sequences were successfully submitted to the NCBI Bankit database (Table 2). Among all bacteria, $A$. veronii was found to be the most prevalent ( 9 nos) followed by $P$. aeruginosa (7 nos).

Table 2 List of bacterial pathogens isolated from various cage farms and their NCBI accession numbers.

\begin{tabular}{|c|c|c|c|c|c|}
\hline $\begin{array}{l}\text { Cage } \\
\text { farms }\end{array}$ & Name of the bacterial isolate & Accession ID & $\begin{array}{l}\text { Cage } \\
\text { farms }\end{array}$ & Name of the bacterial isolate & Accession ID \\
\hline \multirow{6}{*}{ Farm I } & Plesiomonas shigelloides & MK038969 & \multirow{10}{*}{$\begin{array}{l}\text { Farm } \\
\text { III }\end{array}$} & Pseudomonas aeruginosa & MK045608 \\
\hline & Lactococcus lactis & MK026803 & & Pseudomonas aeruginosa & MK045611 \\
\hline & Aeromonas veronii & MK027224 & & Acinetobacter sp. & MK045613 \\
\hline & Pseudomonas aeruginosa & MK026805 & & Acinetobacter baumannii & MK045614 \\
\hline & Aeromonas veronii & MK038967 & & Pseudomonas sp. & MK045615 \\
\hline & Pseudomonas aeruginosa & MK038970 & & Pseudomonas mosselii & MK045617 \\
\hline \multirow{11}{*}{$\begin{array}{l}\text { Farm } \\
\text { II }\end{array}$} & Citrobacter youngae & MK027057 & & Enterobacter cloacae & MK045618 \\
\hline & Morganella morganii & MK027059 & & Pseudomonas entomophila & MK045807 \\
\hline & Plesiomonas shigelloides & MK038971 & & Pseudomonas entomophila & MK027248 \\
\hline & Aeromonas hydrophila & MK038972 & & Enterobacter asburiae & MK045607 \\
\hline & Edwardsiella tarda & MK038966 & \multirow{16}{*}{$\begin{array}{l}\text { Farm } \\
\text { IV }\end{array}$} & Acinetobacter calcoaceticus & MK905213 \\
\hline & Aeromonas hydrophila & MK044848 & & Aeromonas jandaei & MK905214 \\
\hline & Acinetobacter baumannii & MK044849 & & Citrobacter freundii & MK050539 \\
\hline & Plesiomonas shigelloides & MK045606 & & Pseudomonas entomophila & MK045812 \\
\hline & Aeromonas veronii & MK044839 & & Pseudomonas putida & MK045810 \\
\hline & Aeromonas veronii & MK044845 & & Pseudomonas putida & MK050534 \\
\hline & Pseudomonas aeruginosa & MK045621 & & Pseudomonas putida & MK050535 \\
\hline \multirow{9}{*}{$\begin{array}{l}\text { Farm } \\
\text { III }\end{array}$} & Aeromonas veronii & MK045622 & & Pseudomonas putida & MK050536 \\
\hline & Acinetobacter baumannii & MK027249 & & Aeromonas veronii & MK077636 \\
\hline & Klebsiella pneumoniae & MK905218 & & Pseudomonas aeruginosa & MK078036 \\
\hline & Aeromonas veronii & MK050532 & & Enterobacter cloacae & MK078043 \\
\hline & Aeromonas veronii & MK050537 & & Enterobacter asburiae & MK078044 \\
\hline & Klebsiella pneumoniae & MK027254 & & Pseudomonas putida & MK078045 \\
\hline & Aeromonas veronii & MK007964 & & Pseudomonas aeruginosa & MK078046 \\
\hline & Pseudomonas stutzeri & MK050538 & & Pseudomonas sp. & MK078630 \\
\hline & & & & Acinetobacter calcoaceticus & MK079615 \\
\hline
\end{tabular}

Physicochemical parameters of water and soil

The water and soil quality analysis (Table 3 ) reveals that most of the parameters were in the normal range except for less dissolved oxygen $(4.85 \mathrm{ppm})$ and high ammonia (0.3 $\mathrm{ppm}$ ) in the Manoli reservoir.

Prevalence of bacterial infections in cage farms

A total of 240 fishes were examined for bacterial infections from all the farms in which $46.6 \%$ of fishes were infected with bacteria. Aeromonas and Pseudomonas are the most prevalent bacterial infections noticed in all the cage farms whereas other bacterial infections were comparatively less. The Pseudomonas species isolated were $P$. aeruginosa, P. putida, P. entomophila, P. mosselli, and P. stutzeri. A. hydrophila, $A$. veronii, and $A$. jandaei were the Aeromonas species isolated from cage cultured fishes. Prevalence of 
bacterial infections was $14 \%, 22 \%, 42 \%$, and $34 \%$ in cage farms I, II, III, and IV respectively (Table $3 \& \mathbf{4}$ ).

Table 3 Prevalence of major bacterial infections from cage farms I \& II

\begin{tabular}{lllllll}
\hline Farms & Farm I & \multicolumn{5}{l}{ Farm II } \\
\hline Bacterial group & $\begin{array}{l}\text { No. of fishes } \\
\text { examined }\end{array}$ & $\begin{array}{l}\text { No. } \\
\text { fishes } \\
\text { Infected }\end{array}$ & $\begin{array}{l}\text { of } \\
\text { Prevalence } \\
(\%)\end{array}$ & $\begin{array}{l}\text { No. of fishes } \\
\text { examined }\end{array}$ & $\begin{array}{l}\text { No. of fishes } \\
\text { Infected }\end{array}$ & $\begin{array}{l}\text { Prevalence } \\
(\%)\end{array}$ \\
\hline Aeromonas & & 7 & 11.6 & & 11 & 18.3 \\
Pseudomonas & & 4 & 6.6 & & - & - \\
Acinetobacter & & - & - & & 4 & 6.6 \\
Citrobacter & 60 & - & - & 60 & 2 & 3.3 \\
Enterobacter & & - & - & & - & - \\
Pleisomonas & & 2 & 3.3 & & 2 & 3.3 \\
Other infections & & 1 & 1.6 & & 3 & 5 \\
Total & 60 & 14 & 23 & 60 & 22 & 36.6 \\
\hline
\end{tabular}

Table 4 Prevalence of major bacterial infections from cage farms III \& IV

\begin{tabular}{llllllll}
\hline Farms & Farm III & \multicolumn{5}{c}{ Farm IV } \\
\hline Bacterial group & $\begin{array}{l}\text { No. } \\
\text { fishes } \\
\text { examined }\end{array}$ & $\begin{array}{l}\text { No. } \\
\text { fishes } \\
\text { Infected }\end{array}$ & $\begin{array}{l}\text { of } \\
\text { Prevalence } \\
\text { (\%) }\end{array}$ & $\begin{array}{l}\text { No. } \\
\text { fishes } \\
\text { examined }\end{array}$ & $\begin{array}{l}\text { of } \\
\text { fishes } \\
\text { Infected }\end{array}$ & $\begin{array}{l}\text { Prevalence } \\
(\%)\end{array}$ \\
\hline Aeromonas & & 11 & 18.3 & & 8 & 13.3 \\
Pseudomonas & & 19 & 31.6 & & 20 & 33.3 \\
Acinetobacter & & 6 & 10 & & 3 & 5 \\
Citrobacter & 60 & - & & 60 & 1 & 1.6 \\
Enterobacter & & 4 & 6.6 & & 2 & 3.3 \\
Pleisomonas & & - & & & - & - \\
Other infections & & 2 & 3.3 & & - & - \\
Total & 60 & 42 & 70 & 60 & 34 & 57 \\
\hline
\end{tabular}

Antibiotic susceptibility

Antibiotic susceptibility tests indicated that all the bacterial isolates were sensitive to Gentamicin and Ciprofloxacin and most of the isolates were resistant to Ampicillin and Penicillin-G. The percentage of resistant bacteria was $32 \%$ and $28 \%$ for Sulphamethoxazole and Tetracycline respectively (Table 5). An intermediate level of resistance was noted in the case of aminoglycoside antibiotics, i.e., Neomycin, Kanamycin, and Streptomycin.

Histopathological analysis

Significant changes were noticed in the fishes with a high prevalence of Pseudomonas and Aeromonas infections when compared with the control fishes (Figure 4 \& 5). The following alterations observed in the fishes infected with Pseudomonas. Secondary lamellar fusion, epithelial hyperplasia, infiltration of inflammatory cells, curling and necrosis in gill tissue; pyknotic nuclei, congestion, focal area of cellular infiltration, atrophied pancreatic tissue and necrotized hepatocytes in the liver parenchyma; tubular necrosis, infiltration of inflammatory cells, congestion, hypertrophy of tubular epithelial cells with the consequent reduction of tubular lumen were noticed in kidney tissue. Histopathological alterations seen in Aeromonas infected fishes are, secondary lamellar fusion, hyperplasia, curling, atrophy, and necrosis in gill tissue; pyknotic nuclei, vacuolation, hemorrhage, and congestion in the The Israeli Journal of Aquaculture - Bamidgeh • IJA.73.2021.1531522 
liver parenchyma; hemorrhages, tubular necrosis, and hypertrophy of tubular epithelial cells with the consequent reduction of tubular lumen were observed in kidney tissue.

Table 5 Antibiotic susceptibility profile of bacterial isolates

\begin{tabular}{cllll}
\hline SI/no & Name of the Antibiotics & Resistance (\%) & Intermediate (\%) & Susceptible (\%) \\
\hline 1. & Chloramphenicol (30 mcg) & 8 & 4 & 88 \\
2. & Kanamycin (5 mcg) & 4 & 40 & 56 \\
3. Ampicillin (25 mcg) & 96 & - & 4 \\
4. & Sulphamethoxazole (25 mcg) & 32 & 4 & 64 \\
5. Neomycin (30 mcg) & 4 & 60 & 36 \\
6. Tetracycline (10 mcg) & 28 & 24 & 48 \\
7. Penicillin - G (2 units) & 80 & - & 20 \\
8. Streptomycin (25mcg) & 12 & 44 & 44 \\
9. Gentamicin (50mcg) & - & 4 & 96 \\
10. Ciprofloxacin (30mcg) & - & 16 & 84
\end{tabular}

*mcg - micrograms
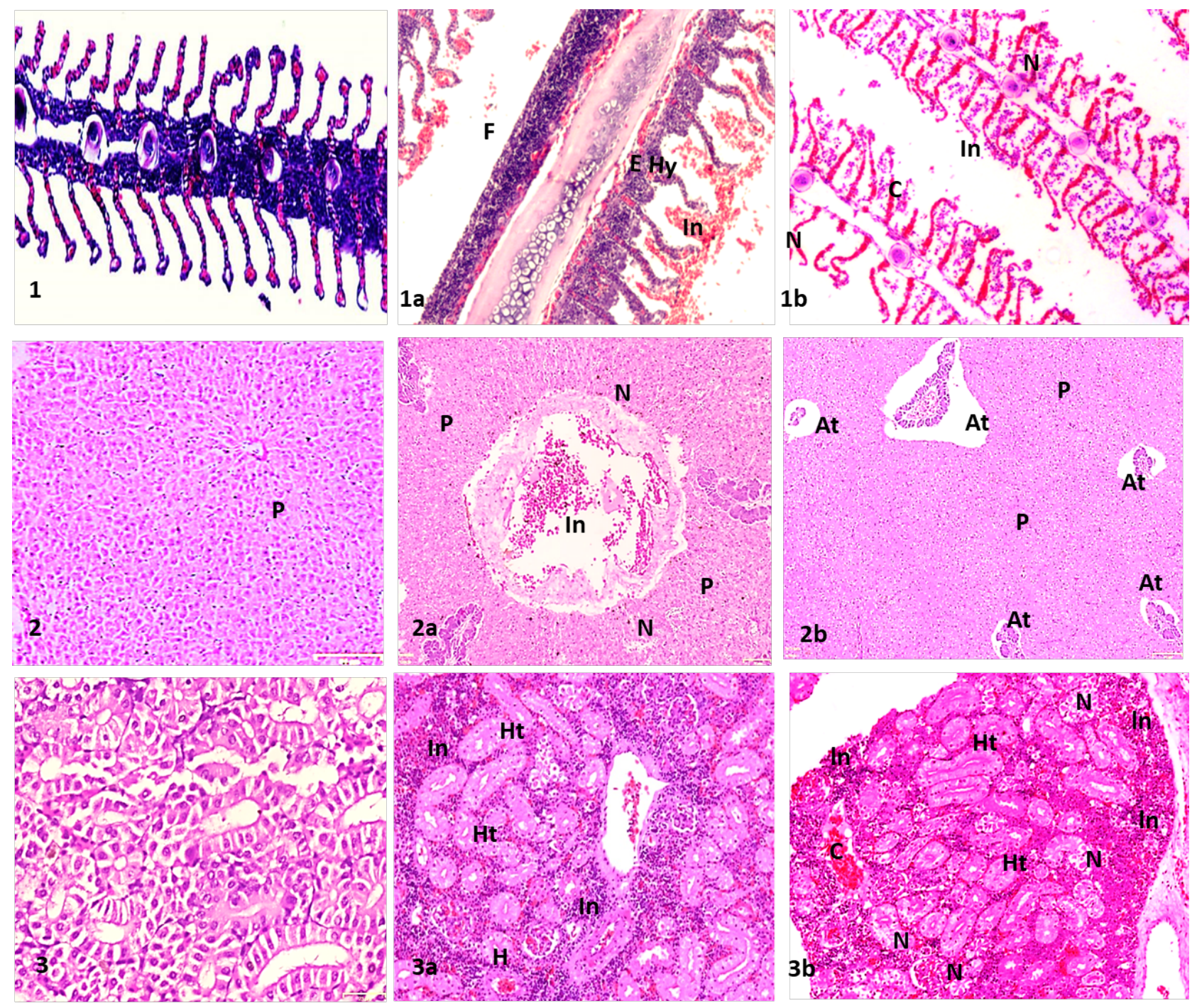

Figure 4 Comparison of the histopathological alterations observed in the vital tissues of fishes infected with Pseudomonas sp. and the healthy fishes. 1) Gill tissue section displaying normal secondary lamella; 1a) Gill tissue displaying epithelial hyperplasia (E hy), infiltration of inflammatory cells (In) and lamellar fusion (F); 1b) Gill section exhibiting curling of secondary lamellae (C), infiltration of inflammatory cells (In) and Necrosis at 
places (N). 2) Liver tissue section exhibiting normal hepatocytes; 2a) Liver tissue exhibiting degenerative changes i.e., necrotized hepatic cells $(\mathrm{N})$, pyknotic nuclei $(\mathrm{P})$ and focal area of cellular infiltration (In); 2a) Liver section displaying congestion at hepatic vessels (C) and pyknotic nuclei (P). 3) Kidney tissue with normal renal tubules; 3a) Kidney tissue displaying degenerative changes i.e., hypertrophy of tubular epithelial cells with consequent reduction in the tubular lumen $(\mathrm{Ht})$ and Infiltration of inflammatory cells in the kidney parenchyma (In); 3b) Kidney section exhibiting tubular necrosis (N) and haemorrhage at places $(\mathrm{H})$.
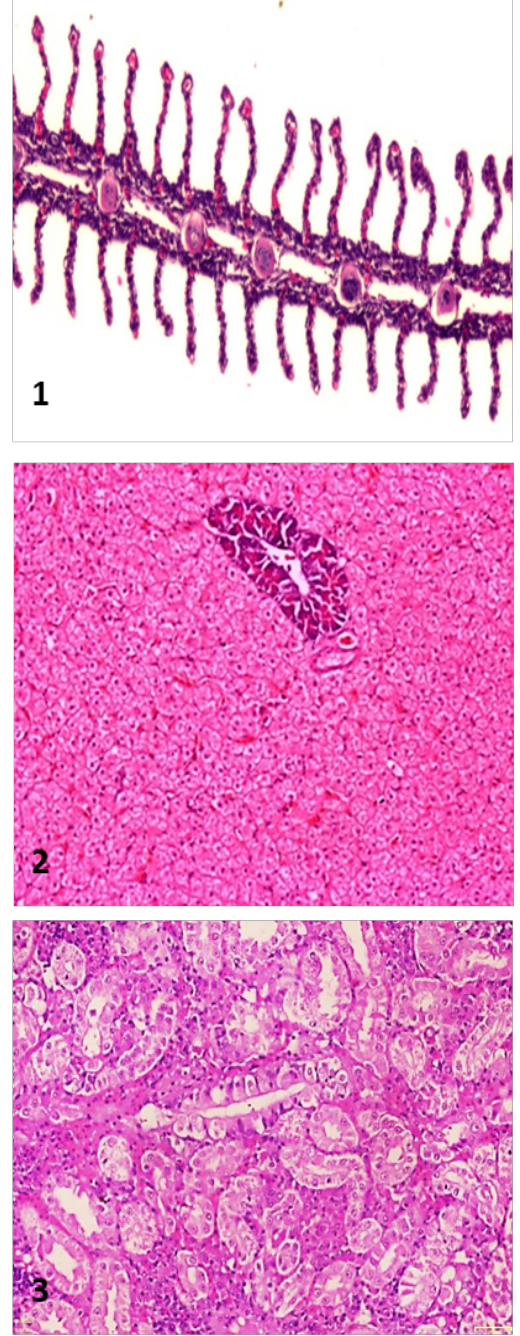
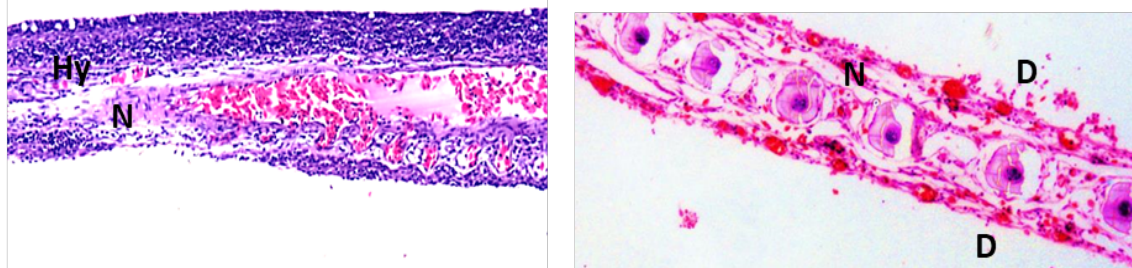

F
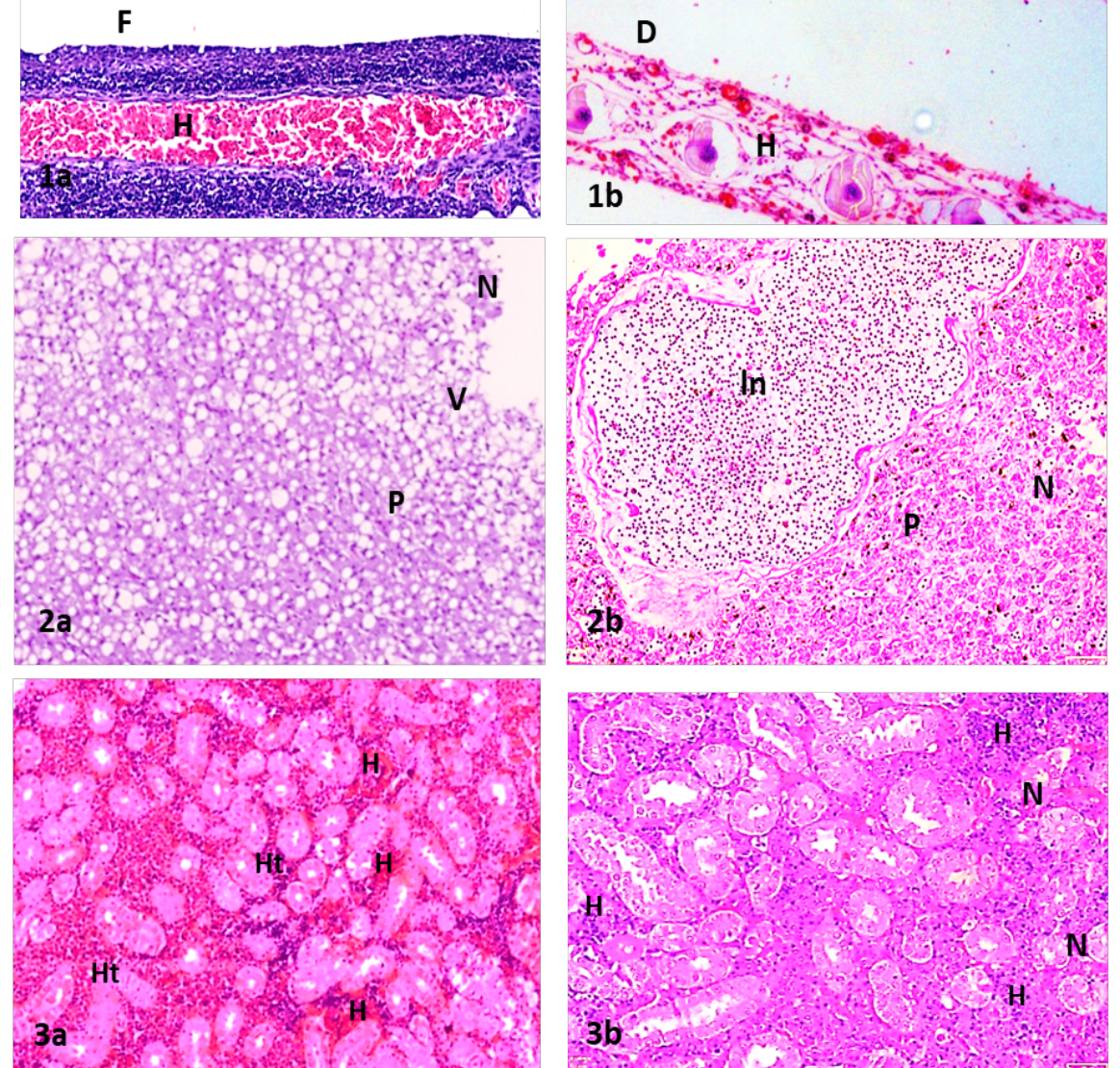

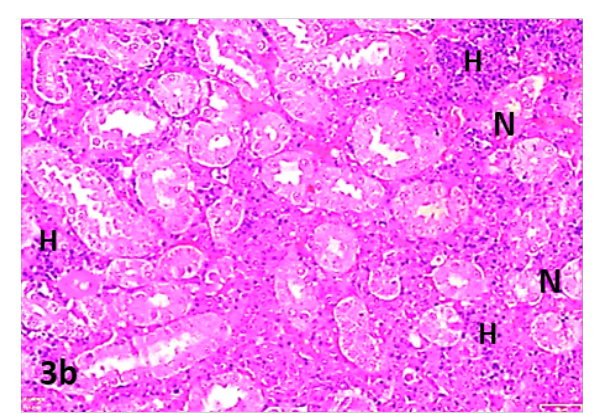

Figure 5 Comparison of the histopathological alterations observed in the vital tissues of fishes infected with Aeromonas sp. and the healthy fishes. 1) Gill tissue section displaying normal secondary lamella; $1 \mathrm{a})$ Gill tissue displaying hyperplasia ( $\mathrm{Hy}$ ) with consequent complete fusion of secondary lamellae $(\mathrm{F})$, necrosis $(\mathrm{N})$ and haemorrhage $(\mathrm{H})$ at places; $1 \mathrm{~b}$ ) Gill section exhibiting haemorrhage $(\mathrm{H})$, necrosis of gill tissue (N) and complete degradation of secondary lamellae (D). 2) Liver tissue section exhibiting normal hepatocytes; 2a) Liver tissue exhibiting necrotized hepatic cells $(\mathrm{N})$, pyknotic nuclei (P) and focal area of cellular infiltration (In); 2a) Liver section displaying congestion at hepatic vessels (C) and pyknotic nuclei (P). 3) Kidney tissue with normal renal tubules; 3a) Kidney tissue displaying degenerative changes i.e., hypertrophy of tubular epithelial cells with consequent reduction in the tubular lumen $(\mathrm{Ht})$ and Infiltration of inflammatory cells in the kidney parenchyma $(\mathrm{In}) ; 3 \mathrm{~b})$ Kidney section exhibiting tubular necrosis $(\mathrm{N})$ and haemorrhage at places $(\mathrm{H})$. 
Principal component analysis

Principal component loadings ( $\mathrm{PC}_{1}$ and $\mathrm{PC}_{2}$ ) of each farm were obtained after principal component analysis of biotic factors and water quality parameters (Table 7). Two axes were formed for each farm in PCA and their cumulative percentage explained was $99.92 \%$, $99.80 \%, 99.53$, and $99.81 \%$ of water quality variations in Farm I, Farm II, Farm III, and Farm IV respectively. In Farm I, $\mathrm{PC}_{1}$ had positive loadings of water temperature, dissolved oxygen, and $\mathrm{pH}$ while in $\mathrm{PC}_{2} \mathrm{pH}$, the prevalence of Aeromonas, Pseudomonas, and Pleisomonas had high loadings (Figure 6). In the case of Farm II, the first axis positive loadings were similar to Farm I whereas the second axis had high loadings of $\mathrm{pH}$, the prevalence of Citrobacter and Pleisomonas (Figure 7). However, for Farm III, water temperature, dissolved oxygen, $\mathrm{pH}$, and the prevalence of Pseudomonas were found to show high loadings in $\mathrm{PC}_{1}$ and phosphate, prevalence of Aeromonas, Pseudomonas and Enterobacter were the high loadings in $\mathrm{PC}_{2}$ (Figure 8). For Farm IV, $\mathrm{PC}_{1}$ had high loadings of water temperature, $\mathrm{pH}$, and the prevalence of Pseudomonas while in $\mathrm{PC}_{2}$ water temperature, dissolved oxygen, $\mathrm{pH}$, nitrite, nitrate, the prevalence of Pleisomonas and other infections were shown high loadings (Figure 9). Overall, significant principal loadings observed are water temperature, dissolved oxygen, and $\mathrm{pH}$ among the water quality parameters and the prevalence of Pseudomonas, Aeromonas and Pleisomonas among the biotic stress factors identified in this study.

Table 7 Principal component loadings from principal component analysis of water quality and bacterial parameters from all the farms

\begin{tabular}{|c|c|c|c|c|c|c|c|c|}
\hline \multirow{2}{*}{ Parameters } & \multicolumn{2}{|c|}{ Farm - I } & \multicolumn{2}{|c|}{ Farm - II } & \multicolumn{2}{|c|}{ Farm - III } & \multicolumn{2}{|c|}{ Farm - IV } \\
\hline & $P C-I$ & $P C-I I$ & $P C-I$ & $P C-I I$ & $P C-I$ & $P C-I I$ & $P C-I$ & $P C-I I$ \\
\hline $\begin{array}{l}\text { Percentage variance } \\
\text { Cumulative variance }\end{array}$ & $\begin{array}{l}99.712 \\
99.712\end{array}$ & $\begin{array}{l}0.213 \\
99.925\end{array}$ & $\begin{array}{l}99.376 \\
99.376\end{array}$ & $\begin{array}{l}0.431 \\
99.807\end{array}$ & $\begin{array}{l}96.936 \\
96.936\end{array}$ & $\begin{array}{l}2.598 \\
99.534\end{array}$ & $\begin{array}{l}95.992 \\
95.992\end{array}$ & $\begin{array}{l}3.818 \\
99.810\end{array}$ \\
\hline Eigen value & 2.991 & 0.006 & 2.981 & 0.013 & 2.908 & 0.078 & 141.867 & 5.643 \\
\hline $\begin{array}{l}\text { Water temperature } \\
\text { Dissolved oxygen } \\
\text { pH }\end{array}$ & $\begin{array}{l}3.276 \\
0.411 \\
0.577\end{array}$ & $\begin{array}{l}-0.242 \\
-0.305 \\
\mathbf{3 5 8}\end{array}$ & $\begin{array}{l}3.264 \\
0.436\end{array}$ & $\begin{array}{l}0.050 \\
0.181\end{array}$ & $\begin{array}{l}3.191 \\
0.345\end{array}$ & $\begin{array}{l}-0.408 \\
-0.626\end{array}$ & $\begin{array}{l}\mathbf{3 . 1 7 0} \\
0.284\end{array}$ & $\begin{array}{l}0.436 \\
1.085\end{array}$ \\
\hline Nitrite & -0.450 & -0.481 & -0.480 & 0.156 & -0.563 & -0.398 & -0.541 & 0.309 \\
\hline Ammonia & -0.428 & -0.352 & -0.451 & 0.091 & -0.554 & -0.383 & -0.521 & 0.256 \\
\hline Nitrate & -0.419 & -0.331 & -0.446 & -0.212 & -0.561 & -0.412 & -0.538 & 0.318 \\
\hline Phos & -0.444 & -0.404 & -0.472 & 0.122 & -0.4 & 0.310 & & -0.207 \\
\hline Aerom & -0.126 & 1.299 & 0.020 & -2.121 & -0.050 & 0.757 & -0.136 & -0.668 \\
\hline Pseudomonas & -0.266 & 1.123 & -0.486 & 0.209 & 0.302 & 3.137 & 0.475 & -3.153 \\
\hline & -0.456 & -0.596 & -0.309 & -0.812 & -0.265 & -0.431 & -0.389 & -0.080 \\
\hline Citrobacter & -0.456 & -0.596 & -0.395 & 0.534 & -0.568 & -0.415 & -0.491 & 0.0005 \\
\hline & & -0.596 & -0.486 & 0.209 & -0.394 & 0.411 & -0.442 & 0.240 \\
\hline Pleisomonas & -0.355 & 2.492 & -0.390 & 2.205 & -0.568 & -0.415 & -0.545 & 0.321 \\
\hline Other infections & -0.409 & -1.368 & -0.352 & -1.377 & -0.478 & -0.314 & -0.545 & 0.321 \\
\hline
\end{tabular}

*Water quality loadings with absolute value $>0.30$ in bold.

\begin{tabular}{lll}
\hline Farms & $P C 1$ & $P C 2$ \\
\hline Farm I & 0.81718 & -1.0341 \\
Farm II & 0.91287 & 1.0045 \\
Farm III & -0.89916 & 0.69341 \\
Farm IV & -0.83089 & -0.66381 \\
\hline
\end{tabular}




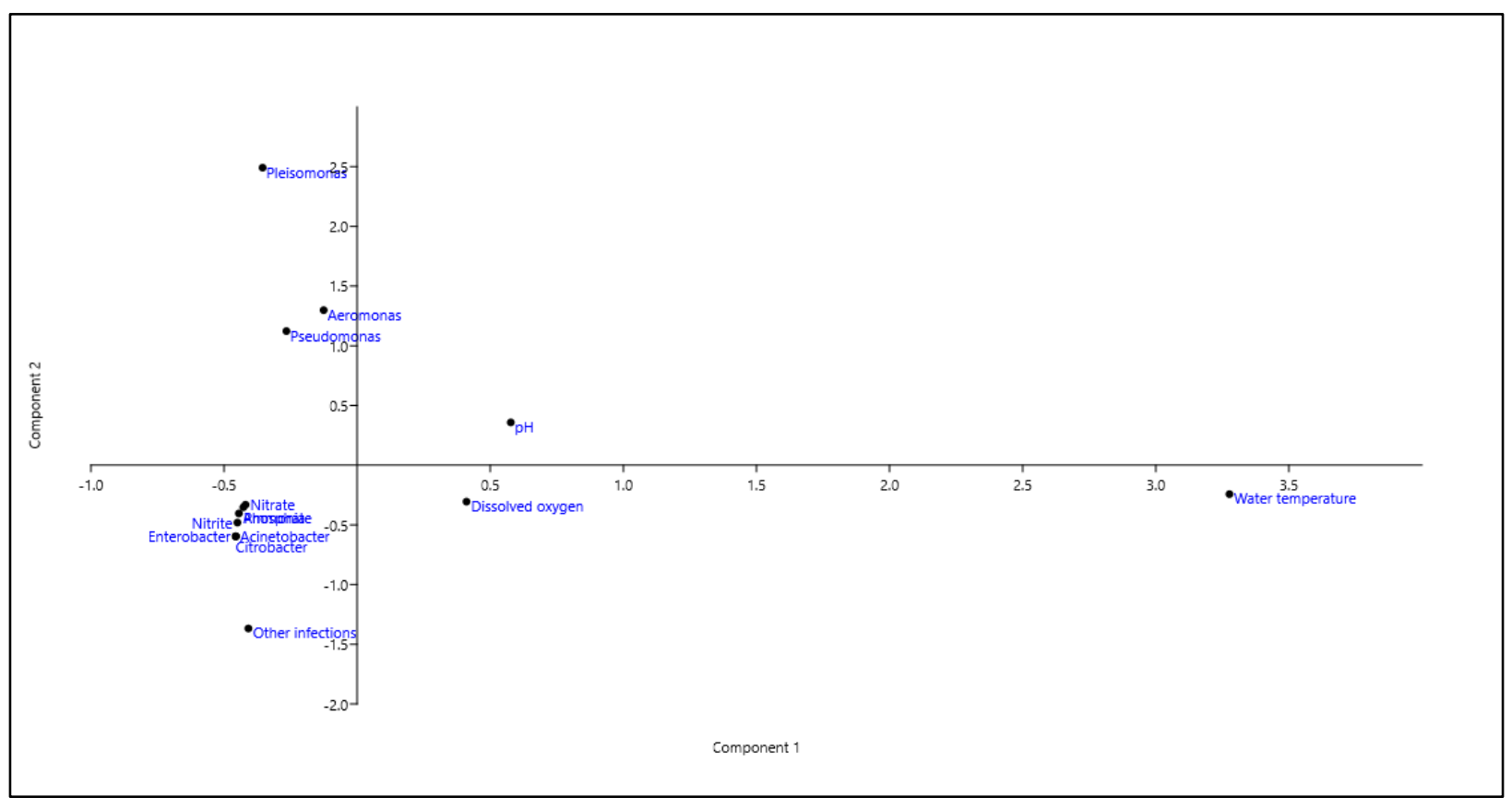

Figure 6 Principal component analysis ordination diagram showing the significant biotic and abiotic factors' loadings associated with Farm I.

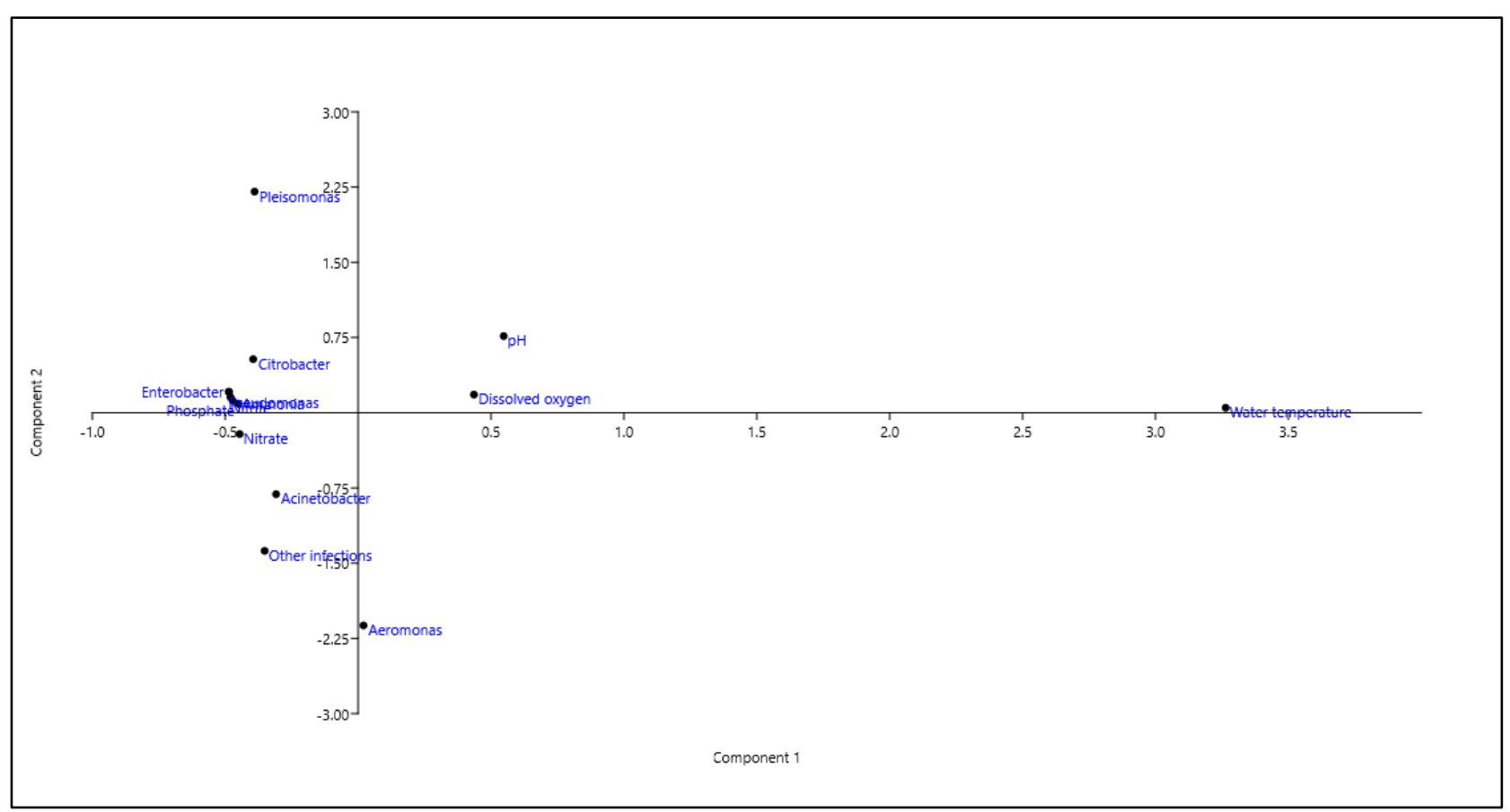

Figure 7 Principal component analysis ordination diagram showing the significant biotic and abiotic stress factors' loadings associated with Farm II. 


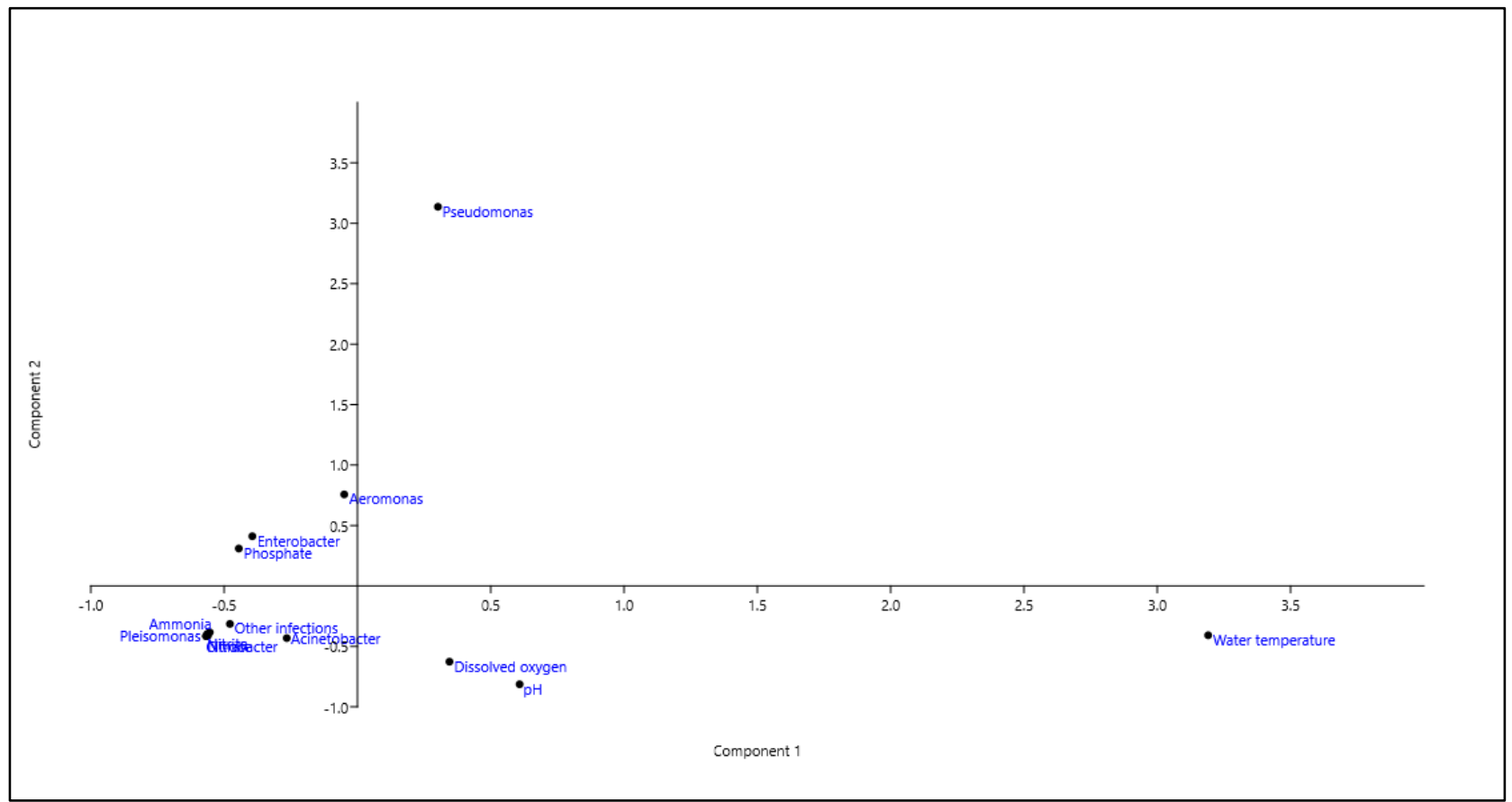

Figure 8 Principal component analysis ordination diagram showing the significant biotic and abiotic stress factors' loadings associated with Farm III.

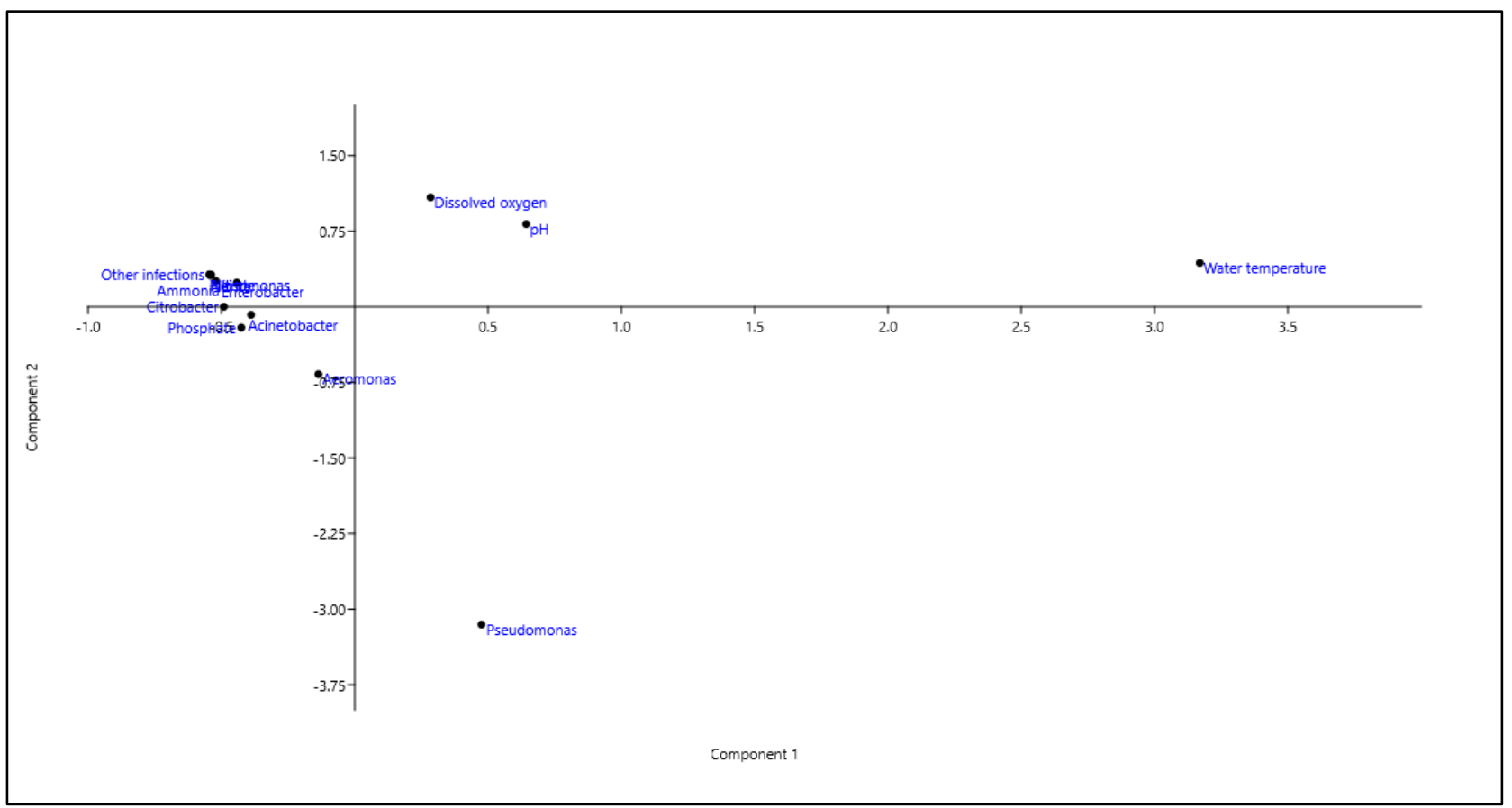

Figure 9 Principal component analysis ordination diagram showing the significant biotic and abiotic stress factors' loadings associated with Farm IV. 


\section{Discussion}

Cage culture is one of the most intense forms of aquaculture and can be prone to disease problems. The natural as well as artificial environmental stress factors have a significant impact on fish health. It has also been reported that acute or chronic exposure to these factors may lead to many infectious disease outbreaks in fishes (Bly et al., 1997). Hence the study was formulated to understand the prevalence of microbes in cage cultured Pangas catfish.

Most of the fish bacterial diseases are caused by gram negative opportunistic bacteria which are generally adapted to the low osmotic condition of the aquatic environment (Austin \& Austin, 2016; Tesfaye et al. 2018). There were nine gram-negative bacteria isolated, whereas Lactococcus is the only gram-positive bacteria found in the present study. Overall, 12 Aeromonas sp, comprising 3 species, i.e., hydrophila, veronii, and jandaei were isolated and characterized during the present investigation. A. hydrophila is responsible for heavy mortality and eliciting septicemic conditions in the Pangas catfishes (Sarkar et al. 2016; Nahar et al. 2016). In fact, Nahar et al. (2016) had isolated 10 virulent strains of $A$. hydrophila from farmed juvenile pangas catfish. Kumar et al. (2015) has isolated a virulent strain of $A$. jandaei from Pangas catfish with the clinical manifestations of reddish lesions near the pectoral fins and belly region. According to our results, $A$. veronii is the most prevalent bacteria isolated. However, information regarding disease outbreaks associated with $A$. veronii in Pangas catfish is not well reported. Besides, $A$. veronii was stated as a causative agent for hemorrhagic septicemia in various fish species (Sreedharan et al. 2013; Eissa et al. 2015; Hassan et al. 2017).

During our study, E. tarda was isolated from the kidney of Pangas catfish with the reddish lesion in the mouth and fins without any significant mortality of fishes in the cages. Similar findings were acquired by Shetty et al. (2014), who isolated E. tarda from the clinically manifested Pangas catfish with no mortality but they could reciprocate the clinical signs during the experimental infection. From the present study, Lactococcus sp identified without any obvious clinical signs which are previously known as probiotic bacteria (Balcazar et al. 2008). Recently it has been reported as a causative agent of Lactococcosis, responsible for a $100 \%$ loss of hybrid sturgeons (Huso huso $\times$ Acipenser ruthenus) in a fish farm in Taiwan, China (Chen et al. 2012).

A highly diverse group of Pseudomonas comprising species namely, $P$. entomophila, $P$. putida, $P$. aeruginosa, $P$. mosselii, and $P$. stutzeri were identified in different reservoirs. $P$. aeruginosa is well known as an opportunistic pathogen for Oreochromis mossambicus (Thomas et al. 2014) and Clarias gariepinus (Khairnar et al. 2013) but it is not yet reported as a disease-causing bacterium in Pangasius. Out of two species of Acinetobacter ( $A$. baumannii, $A$. calcoaceticus) identified from the present investigation, $A$. baumannii is well reported as a multi-drug resistant pathogen associated with the eye infection of Channa striatus in India (Rauta et al. 2011). However, Reddy and Mastan (2013) have reported $A$. schindleri associated with red-eye infection of Pangasius sutchi. P. shigelloides identified from our study is a pathogenic bacterium to Ctenopharyngodon idella (Hu et al. 2014), $O$. nilotica (Nisha et al. 2014; Liu et al. 2015), and Hypophthalmichthys molitrix (Behera et al. 2018).

Some of the human bacterial pathogens were isolated namely $C$. youngae, $A$. baumannii, K. pneumoniae, M. morganii, A. calcoaceticus, P. shigelloides (enteric disease), and C. freundii from this study (Falagas et al. 2006; McConnell et al. 2013). These are mostly associated with food-borne zoonotic diseases and multi-drug resistance issues in humans. Isolation of such a high number of zoonotic bacterial pathogens from the open water culture system increases the public health concern associated with farmed fish consumption (Cantas and Suer, 2014).

Multivariate analyses displayed that water temperature, dissolved oxygen, $\mathrm{pH}$, phosphate, nitrite, and nitrate were vital in at least one of the farms that were associated with the prevalence of bacteria. Similar results were observed by Amal et al. 2013 in cage cultured red hybrid tilapia. They reported that water temperature, dissolved oxygen, $\mathrm{pH}$, and ammonia exhibited a notable correlation with the presence of Streptococcus $s p$ in the cage 
culture system. Unfavorable water quality is well discussed as a significant stress factor, influencing the presence of pathogenic and non-pathogenic bacterial communities in aquaculture systems (Amal et al. 2013; Ismail et al. 2016). Apart from influencing the host immune system, the environmental factors also significantly alter the pathogen life cycle, abundance, and host range (Schade et al. 2015). Karvonen et al. (2010) has reported that the increased water temperature has a dynamic influence on the prevalence of bacterial and parasitic fish diseases. According to the investigation by several authors, the intensity of gram-negative opportunistic bacteria such as P. aeruginosa, Escherichia coli, $A$. baumannii, and Enterobacter cloacae (Psoter et al. 2013; Schwab et al. 2015) have increased during summer as compared to gram positive bacteria. Our research findings also in agreement with the previous reports that the patterns of selected bacterial diseases have also been increased at a higher temperature.

The prevalence of Pseudomonas sp, Aeromonas sp and Acinetobacter sp has increased when the water temperature was around $29^{\circ} \mathrm{C}$. The increased rate of bacterial replication and transmission could be the reason for such enhanced prevalence in summer. The report from Ramos et al. (2013), explains that the prevalence of Pseudomonas increases during the summer irrespective of their species. Our study pertains to the reports of the high prevalence of Pseudomonas species during summer. The impact of environmental factors like temperature, humidity, and precipitation are a plausible explanation for such increment in Pseudomonas prevalence. However, we have also noted low dissolved oxygen $(4.85 \mathrm{mg}$ $\mathrm{L}^{-1}$ ) concentration in particular reservoirs with high Pseudomonas abundance.

The most significant histopathological changes observed in gills, liver, kidney, and intestinal tissues in the fishes isolated with Pseudomonas and Aeromonas sp are suggestive of biotic stress in the reservoirs. Similar histopathological observations were reported by Ventura and Grizzle (1988); Candan (1990) due to bacterial infection in fishes. Kumar (2015) reported some important histological observations during the bacterial infection in the liver, kidney and gill tissues of pangas catfishes. Similar pathogens were also identified and isolated in the present study with the reported histological changes in the gill, kidney, and liver tissue.

The misuse of antibiotics has so long been discussed in aquaculture and many of them are banned in India (Aich et al. 2018). In the present study, isolated bacteria have shown resistance to Ampicillin (96\%), Penicillin-G (80\%), Sulphamethoxazole (32\%), and Tetracycline (28\%). While resistance to Ampicillin and Penicillin is intrinsic for most of the gram-negative bacteria (Munita and Arias, 2016; Exner et al. 2017), Tetracycline and Sulphamethoxazole are frequently used antibiotics for treating bacterial infection. Bacterial resistance to antibiotics reduces their application in disease control. Similarly, Sarter et al. (2007) reported multidrug resistance to Ampicillin, Oxytetracycline, and Sulphamethoxazole in bacteria isolated from the Pangas catfish. Bacteria isolated from other cage cultured fishes were also have shown drug resistance. Some of the resistant genes can also be horizontally transferred to other environmental microbes and human pathogenic bacteria which pose a risk for human health (Boran et al. 2013).

\section{Conclusion}

The present paper describes the prevalence of bacteria in the enclosure environment. Higher prevalence of opportunistic bacterial pathogens, in particular Pseudomonas and Aeromonas spp. indicates the presence of immense biotic stress to the fishes in cages. The disease susceptibility of fishes can be minimized by mitigating the stress factors in cages. For instance, optimum water and soil quality, ideal feeding, and stocking density and application of Immunostimulants can reduce disease loss in cages. The presence of zoonotic pathogens could also be a serious public health risk to fish consumers. Investigation and identification of specific risk factors will be helpful for spreading awareness regarding disease control and prevention strategies. 


\section{Acknowledgement}

The authors are thankful to Dr. Gopal Krishna, Director/Vice-Chancellor of ICAR-Central Institute of Fisheries Education, Mumbai, India, for providing support and necessary facilities to conduct the present study.

\section{References}

Aich, N., Ahmed, N., Paul, A., 2018. Issues of Antibiotic Resistance in Aquaculture Industry and Its Way Forward. International Journal of Current Microbiology and Applied Science. 7(8): 26-41. https://doi.org/10.20546/ijcmas.2018.708.004

Amal, M.N.A., Zamri-Saad, M., Siti-Zahrah, A., Zulkafli, A.R., 2013. Transmission of Streptococcus agalactiae from a hatchery into a newly established red hybrid tilapia, Oreochromis niloticus (L.) $\times$ Oreochromis mossambicus (Peters), farm. Journal of Fish Diseases. 36(8): 735-739. https://doi.org/10.1111/jfd.12056

Amal, M.N.A., Saad, M.Z., Zahrah, A.S., Zulkafli, A.R., 2013. Water quality influences the presence of Streptococcus agalactiae in cage cultured red hybrid tilapia, Oreochromis niloticus $\times$ Oreochromis mossambicus. Aquaculture Research, 46(2): 313-323. https://doi.org/10.1111/are.12180

American Public Health Association, American Water Works Association, Water Pollution Control Federation and Water Environment Federation. (2005). Standard methods for the examination of water and wastewater. American Public Health Association, Washington, D.C., pp.105-107.

Austin, B., 2016. Aeromonadaceae representatives (motile aeromonads), pp. 119-146. In: B. Austin, D. A. Austin, (6). Bacterial Fish Pathogens. Springer International Publishing., Switzerland, 652. ISBN 978-3-319-32673-3. ISBN 978-3-319-32674-0. https://doi.org/10.1007/978-3-319-32674-0

Austin, B. and Austin, D.A. 2012. Bacterial fish pathogens, Disease of Farmed and Wild Fish. fifth eds. Springer, Netherlands. 652pp. ISBN 978-3-319-32673-3

Balcázar, J.L., Vendrell, D., de Blas, I., Ruiz-Zarzuela, I., Muzquiz, J.L., Girones, O. 2008. Characterization of probiotic properties of lactic acid bacteria isolated from intestinal microbiota of fish. Aquaculture. 278: 188-191. https://doi.org/10.1016/j.aquaculture.2008.03.014

Bly, J.E., Quiniou, S.M., Clem, L.W., 1997. Environmental effects on fish immune mechanisms. Developments in biological standardization. 90: 33-43. PMID: 9270832.

Boran, H., Terzi, E., Altinok, I., Capkin, E., Bascinar, N., 2013. Bacterial diseases of cultured Mediterranean horse mackerel (Trachurus mediterraneus) in sea cages. Aquaculture. 396: 8-13. https://doi.org/10.1016/j.aquaculture.2013.02.025

Boyd, C.E., Tucker, C.S., 1998. Pond Aquaculture Water Quality Management. Kluwer Academic Publishers, USA.

Behera, B.K., Bera, A.K., Paria, P., Das, A., Parida, P.K., Kumari, S., Bhowmick, S., Das, B.K., 2018. Identification and pathogenicity of Plesiomonas shigelloides in Silver Carp. Aquaculture. 493: 314-318. https://doi.org/10.1016/j.aquaculture.2018.04.063

Cantas, L., Suer, K., 2014. The important bacterial zoonoses in "one health" concept. Frontiers in Public Health. 2: 144. https://doi.org/10.3389/fpubh.2014.00144

Candan, A.A., 1990. A study on the histopathology of Aeromonas hydrophila infections of rainbow trout (Salmo gairdineri R.) kept under experimental conditions and the effect of Chloramphenicol. Journal of Aquatic Food Product Technology. 4: 5-20.

Chen, M.H., Hung, S.W., Shyu, C.L., Lin, C.C., Liu, P.C., Chang, C.H., Shia, W.Y., Cheng, C.F., Lin, S.L., Tu, C.Y., Lin, Y.H., Wang, W.S., 2012. Lactococcus lactis Subsp. Lactis Infection in Bester Sturgeon, a Cultured Hybrid of Huso huso $\times$ Acipenser ruthenus, in Taiwan. Research in Veterinary Science. 93: 581-588. https://doi.org/10.1016/j.rvsc.2011.10.007

Chitmanat, C., Lebel, P., Whangchai, N., Promya, J., Lebel, L., 2016. Tilapia diseases and management in river-based cage aquaculture in northern Thailand. Journal of Applied Aquaculture. 28: 9-16. https://doi.org/10.1080/10454438.2015.1104950 
Clinical and Laboratory Standards Institute, 2009. Performance Standards for Antimicrobial Susceptibility Testing: Nineteenth Informational Supplement M100-S19. Wayne, PA: CLSI. Collins, C. M., 1988. Rearing channel catfish in cages. Part II. Aquaculture. 14, 56-58. Crumlish, M., Dung, T.T., Turnbull, J.F., Ngoc, N.T.N., Ferguson, H.W., 2002. Identification of Edwardsiella ictaluri from diseased freshwater catfish, Pangasius hypophthalmus (Sauvage), cultured in the Mekong Delta, Vietnam. Journal of Fish Diseases. 25: 733-736. https://doi.org/10.1046/j.1365-2761.2002.00412

Duncan, D.B., 1955. Multiple range and multiple F tests. Biometrics, 11: 1-42.

Eissa, I.A.M., El-lamei, M., Sherif, M., Desuky, M., Zaki, M.S., Bakry, M., 2015. Aeromonas veronii biovar sobria a causative agent of mass mortalities in cultured Nile Tilapia in El-Sharkia governorate, Egypt. Life Science Journal. 12: 90-97.

Exner, M., Bhattacharya, S., Christiansen, B., Gebel, J., Goroncy-Bermes, P., Hartemann, P., Heeg, P., Ilschner, C., Kramer, A., Larson, E., Merkens, W., 2017. Antibiotic resistance: What is so special about multidrug-resistant gram-negative bacteria? GMS Hygiene and Infection Control. 12. https://doi.org/10.3205/dgkh000290

Falagas, M.E., Koletsi, P.K., Bliziotis, I.A., 2006. The diversity of definitions of multidrug-resistant (MDR) and pandrug-resistant (PDR) Acinetobacter baumannii and Pseudomonas aeruginosa. Journal of Medical Microbiology. 55, 1619-1629. https://doi.org/10.1099/jmm.0.46747-0

Ferguson, H.W., Turnbull, J.F., Shinn, A.P., Thompson, K., Dung, T.T., Crumlish, M., (2001). Bacillary necrosis in farmed Pangasius hypophthalmus (Sauvage) from the Mekong Delta, Vietnam. Journal of Fish Diseases. 24: 509-513. https://doi.org/10.1046/j.1365-2761.2001.00308.x

Hassan, M.A., Noureldin, E.A., Mahmoud, M.A., Fita, N.A., 2017. Molecular identification and epizootiology of Aeromonas veronii infection among farmed Oreochromis niloticus in Eastern Province, KSA. Egyptian Journal of Aquatic Research. 43, 161-167. http://dx.doi.org/10.1016/j.ejar.2017.06.001

Hu, Q., Lin, Q., Shi, C., Fu, X., Li, N., Liu, L., \& Wu, S., 2014. Isolation and identification of a pathogenic Plesiomonas shigelloides from diseased grass carp. Acta Microbiologica Sinica. 54: 229-235. PMID: 24818472.

Ismail, N.I.A., Amal, M.N.A., Shohaimi, S., Saad, M.Z., \& Abdullah, S.Z., 2016. Associations of water quality and bacteria presence in cage cultured red hybrid tilapia, Oreochromis niloticus $\times$ O. mossambicus. Aquaculture Reports, 4: 57-65.

Karvonen, A., Rintamäki, P., Jokela, J., \& Valtonen, E.T., 2010. Increasing water temperature and disease risks in aquatic systems: climate change increases the risk of some, but not all, diseases. International Journal of Parasitology. 40: 1483-1488. https://doi:10.1016/j.ijpara.2010.04.015

Khairnar, K., Raut, M.P., Chandekar, R.H., Sanmukh, S.G., Paunikar, W.N., 2013. Novel bacteriophage therapy for controlling metallo-beta-lactamase producing Pseudomonas aeruginosa infection in catfish. BMC Veterinary Research. 9: 264. https://doi.org/10.1186/1746-6148-9-264

Kumar, K., Prasad, P., Raman, R.P., Kumar, S., Purushothaman, C.S., 2013. Association of Enterobacter cloacae in the mortality of Pangasianodon hypophthalmus (Sauvage, 1878) reared in culture pond in Bhimavaram, Andhra Pradesh, India. Indian Journal of Fisheries. 60: 147-149.

Kumar, K., Prasad, K.P., Tripathi, G., Raman, R.P., Kumar, S., Tembhurne, M., Purushothaman, C.S., 2015. Isolation, identification, and pathogenicity of a virulent Aeromonas jandaei associated with mortality of farmed Pangasianodon hypophthalmus, in India. The Israeli journal of aquaculture, Bamidgeh. 23: 87-94. http://hdl.handle.net/10524/49172 https://doi.org/10.46989/001c.20727

Liu, Z., Ke, X., Lu, M., Gao, F., Cao, J., Zhu, H., Wang, M., 2015. Identification and pathological observation of a pathogenic Plesiomonas shigelloides strain isolated from cultured tilapia (Oreochromis niloticus). Acta Microbiologia Sinica. 55: 96-106. PMID: 25958688.

Luna, A.G., 1968. Manual of histology and special staining technique. Armed Force Institute of Pathology, Magraw Hill Book Co, London. 
Masser, M., Duarte, S., Frutal, T., 1991. Catfish cage farming survey: timely information. Alabama Cooperative Extension Service, Auburn University, Auburn.

McConnell, M.J., Actis, L., Pachón, J., 2013. Acinetobacter baumannii: human infections, factors contributing to pathogenesis and animal models. FEMS Microbiology Reviews. 37: 130-155. https://doi.org/10.1111/j.1574-6976.2012.00344.x

Munita, J.M., \& Arias, C.A., 2016. Mechanisms of antibiotic resistance. Virulence mechanisms of bacterial pathogens. 5: 481-511. https://doi.org/10.1128/9781555819286.ch17

Nahar, S., Rahman, M.M., Ahmed, G.U., Faruk, M.R., 2016. Isolation, identification, and characterization of Aeromonas hydrophila from juvenile farmed pangasius (Pangasianodon hypophthalmus). International Journal of Fisheries and Aquatic Studies. 4: 52-60.

NFDB, 2016. Guidelines for cage culture in inland open water bodies of India. Hyderabad. Nisha, R.G., Rajathi, V., Manikandan, R., Prabhu, N.M., 2014. Isolation of Plesiomonas shigelloides from infected cichlid fishes using 16S rRNA characterization and its control with probiotic Pseudomonas sp. Acta Scientiae Veterinariae. 42: 1-7. https://www.redalyc.org/articulo.oa?id=289029240019

Phan, L.T., Bui, T.M., Nguyen, T.T., Gooley, G.J., Ingram, B.A., Nguyen, H.V., Nguyen, P.T., De Silva, S.S., 2009. Current status of farming practices of striped catfish, Pangasianodon hypophthalmus in the Mekong Delta, Vietnam. Aquaculture. 296(3), 227236. https://doi.org/10.1016/j.aquaculture.2009.08.017

Psoter, K.J., De Roos, A.J., Wakefield, J., Mayer, J., \& Rosenfeld, M., 2013. Season is associated with Pseudomonas aeruginosa acquisition in young children with cystic fibrosis. Clinical Microbiology and Infection. 19: e483-e489. https://doi.org/10.1111/1469-0691.12272

Ramos, G.P., Rocha, J.L., Tuon, F.F., 2013. Seasonal humidity may influence Pseudomonas aeruginosa hospital-acquired infection rates. International Journal of Infectious Diseases. 17: e757-e761. https://doi.org/10.1016/j.ijid.2013.03.002

Rauta, P.R., Kumar, K., Sahoo, P.K., 2011. Emerging new multi-drug resistant bacterial pathogen, Acinetobacter baumannii associated with snakehead Channa striatus eye infection. Current Science India. 101: 548-553. https://www.jstor.org/stable/24078990

Reddy, M.R.K., Mastan, S.A., 2013. Emerging Acinetobacter schindleri in red eye infection of Pangasius sutchi. African Journal of Biotechnology. 12: 6993-6996. https://doi.org/10.5897/AJB2013.12342

Sarkar, M., Saha, P., Roy., 2012. Identification and typing of Aeromoans hydrophila through 16s rDNA-PCR Fingerprinting. Aquaculture Research. 3: 4. https://doi.org/10.4172/2155-9546.1000146

Sarkar, J., Faruk, M.A.R., 2016. Experimental infection of Aeromonas hydrophila in $\begin{array}{llll}\text { pangasius. } & \text { Progressive } & \text { agriculture. } & \text { 392-399. }\end{array}$ https://www.banglajol.info/index.php/PA/article/view/30836

Sarter, S., Nguyen, H.N.K., Lazard, J., Montet, D., 2007. Antibiotic resistance in gramnegative bacteria isolated from farmed catfish. Food Control. 18(11): 1391-1396. https://doi.org/10.1016/j.foodcont.2006.10.003

Schade, F.M., Raupach, M.J., Wegner, K.M., 2015. Seasonal variation in parasite infection patterns of marine fish species from the Northern wadden sea in relation to interannual temperature fluctuations. Journal of Sea Research. 113: 73-84. http://dx.doi.org/10.1016/j.seares.2015.09.002

Schwab, F., Gastmeier, P., Meyer, E., 2015. The warmer the weather, the more gramnegative bacteria impact of temperature on clinical isolates in intensive care units. PloS one. 9(3). https://doi.org/10.1371/journal.pone.0091105

Shetty, M., Maiti, B., Venugopal, M.N., Karunasagar, I., Karunasagar, I., 2014. First isolation and characterization of Edwardsiella tarda from diseased striped catfish, Pangasianodon hypophthalmus (Sauvage). Journal of Fish Diseases. 37: 265-271. https://doi.org/10.1111/jfd.12039 
Sreedharan, K., Philip, R., Singh, I.S.B., 2013. Characterization and virulence potential of phenotypically diverse Aeromonas veronii isolates recovered from moribund freshwater ornamental fishes of Kerala, India. Antonie van Leeuwenhoek. 103: 53-67. https://doi.org/10.1007/s10482-012-9786-z

Tesfaye, S., Kasye, M., Chane, M., Bogale, B., Agere, Z.A., 2018. Preliminary survey of gram-negative bacterial pathogens from commonly caught fish species (Oreochromis niloticus, Cyprinus carpio and Clarias gariepinus) in Lake Hayiq, Ethiopia. Fisheries and Aquaculture Journal. 9: 2-9. https://doi.org/10.4172/2150-3508.1000238

Thomas, J., Thanigaivel, S., Vijayakumar, S., Acharya, K., Shinge, D., Seelan, T.S.J., Mukherjee, A., Chandrasekaran, N., 2014. Pathogenicity of Pseudomonas aeruginosa in Oreochromis mossambicus and treatment using lime oil nano-emulsion. Colloids and Surfaces B. 116, 372-377. https://doi.org/10.1016/j.colsurfb.2014.01.019

Ventura, M.T., Grizzle, J.M., 1988. Lesions associated with natural and experimental infections of Aeromonas hydrophila in channel catfish Ictalurus punctatus (Rafinesque). Journal of Fish Diseases. 11: 397-407. https://doi.org/10.1111/j.13652761.1988.tb00735.x

Vezzulli, L., Chelossi, E., Riccardi, G., Fabiano, M., 2002. Bacterial community structure and activity in fish farm sediments of the Ligurian sea (Western Mediterranean). Aquaculture International. 10: 123-141.

Zamri-Saad, M., Amal, M.N.A., Siti-Zahrah, A., Zulkafli, A.R., 2014. Control and prevention of streptococcosis in cultured tilapia in Malaysia: a review. Pertanika Journal of Tropical Agricultural Science. 37: 389-410. 